\title{
Tindakan Menghardik Untuk Mengatasi Halusinasi Pendengaran Pada Klien Skizofrenia Di Rumah Sakit Jiwa
}

\author{
Murni Pratiwi', Heri Setiawan² \\ 1) Akademi Keperawatan Al Kautsar Temanggung \\ ${ }^{2)}$ Rumah Sakit Jiwa Prof Dr Soerojo Magelang
}

Korespondensi penulis: herirsjs09@yahoo.com

\begin{abstract}
Abstrak
Halusinasi merupakan gangguan penerimaan pancaindra tanpa ada stimulus eksternal, akibat yang ditimbulkan halusinasi dapat membahayakan dirinya sendiri, orang lain, maupun lingkungan disekitarnya yang bersifat merugikan. Penelitian ini akan mengukur menghardik untuk mengatasi halusinasi pendengaran pada klien skizofrenia di rumah sakit jiwa. Teknik analisis yang digunakan studi kasus. Hasil penelitian menunjukan bahwa tanda gejala halusinasi menurun setelah dilakukan tindakan menghardik.
\end{abstract}

Kata Kunci: halusinasi; menghardik; skizofrenia

\section{PENDAHULUAN}

Satu dari empat orang dewasa akan mengalami masalah kesehatan jiwa pada satu waktu dalam hidupnya. Setiap 40 detik di suatu tempat di dunia ada seseorang yang meninggal karena bunuh diri (WFMH, 2016). Data WHO (2016) menunjukkan, terdapat sekitar 35 juta orang terkena depresi, 60 juta orang terkena bipolar, 21 juta terkena skizofrenia (Hari Kesehatan Jiwa Indonesia, 2016). Di Indonesia prevalensi gangguan jiwa berat, seperti skizofrenia adalah 1,7 per 1000 penduduk atau sekitar 400.000 orang (Riskesdas, 2013).

Gangguan jiwa salah satunya skizofrenia, skizofrenia merupakan suatu gangguan jiwa berat yang ditandai dengan penurunan atau ketidakmampuan komunikasi, gangguan realitas (halusinasi atau waham), afek tidak wajar atau tumpul, gangguan kognitif (tidak mampu berpikir abstrak) serta mengalami kesukaran melakukan aktivitas sehari-hari. Gejala yang timbul pada skizofrenia salah satunya halusinasi. Halusinasi merupakan gangguan penerimaan pancaindra tanpa ada stimulus eksternal (halusinasi pendengaran, penglihatan, pengecapan, penciuman, dan perasaan) (Keliat, 2011). Skizofrenia merupakan gangguan jiwa berat atau kronik dengan gejala salah satunya halusinasi.

Menurut Stuart dan Laraia (2005) dalam Muhith (2015) klien yang mengalami halusinasi dapat kehilangan kontrol dirinya sehingga bisa membahayakan dirinya, orang lain maupun lingkungan. Klien benarbenar kehilangan kemampuan penilaian realitas terhadap lingkungan. Dalam situasi ini, klien dapat melakukan bunuh diri (suicide), membunuh orang lain (homicide), dan bahkan merusak lingkungan. Selain masalah yang diakibatkan oleh halusinasi biasanya juga mengalami masalah keperawatan yang menjadi penyebab (triger) munculnya halusinasi. Masalah-masalahnya antara lain harga diri rendah dan 
isolasi sosial. Akibat yang ditimbulkan halusinasi dapat membahayakan dirinya sendiri, orang lain, maupun lingkungan disekitarnya yang bersifat merugikan.

Upaya yang dilakukan untuk mengatasi halusinasi selama ini salah satunya dengan menggunakan menghardik halusinasi (Dermawan, 2013). Berdasarkan penulisan Ninik Retno (2016) yang dilakukan di RSJD Dr. Arif Zainudin Surakarta pada salah satu klien yang mengalami halusinasi pendengaran, untuk mengatasi halusinasi yang sudah dilakukan bahwa intensitas halusinasi sudah berkurang ditandai dengan klien mengontrol rasa takut saat halusinasi muncul setelah belajar pengontrolan halusinasi dan halusinasi sudah tidak muncul ketika dimalam hari dengan melakukan ketiga SP (Strategi Pelaksanan) yaitu, SP 1 menghardik halusinasi, SP 2 bercakapcakap dengan orang lain, SP 3 mengkonsumsi obat secara teratur.

Tindakan keperawatan klien halusinasi meliputi membantu klien mengenali halusinasi tentang isi halusinasi (apa yang didengar/dilihat), waktu terjadi halusinasi, frekuensi terjadinya halusinasi, situasi yang menyebabkan halusinasi muncul dan respon klien saat halusinasi muncul. Latihan klien mengontrol halusinasi dengan salah satu cara dapat mengendalikan halusinasi yaitu menghardik halusinasi dengan cara menolak halusinasi yang muncul (Dermawan, 2013). Tindakan keperawatan yang digunakan untuk mengatasi halusinasi meliputi mengenal halusinasi, melatih klien mengontrol halusinasi dengan cara menghardik atau menolak halusinasi.

Berdasarkan riset terdahulu yang sudah dilakukan dengan judul "Upaya menurunkan kekambuhan pada klien halusinasi menggunakan anti psikotik" di RSUD Dr. Arif Zainudin Surakarta menggunakan metode deskriptif dengan hasil klien mampu mengontrol dan menurunkan kekambuhan dengan menghardik, mengkonsumsi obat teratur dan bercakap-cakap dengan orang lain ditandai dengan hasil halusinasi sudah tidak muncul dimalam hari dengan melakukan ketiga SP (Strategi Pelaksanan) yaitu, SP 1 menghardik halusinasi, SP 2 bercakap-cakap dengan orang lain, SP 3 menggunakan obat secara teratur (Retno, 2016).

Sedangkan menurut penulisan yang dilakukan oleh Suheri (2014) dengan judul "Pengaruh Tindakan Generalis Halusinasi Terhadap Frekuensi Halusinasi Pada Klien Skizofrenia di Rumah Sakit Jiwa Grhsia PEMDA DIY" dengan hasil frekuensi halusinasi klien skizofrenia setelah pemberian tindakan generalis halusinasi, 83,3\% responden pada kelompok eksperimen memiliki frekuensi halusinasi pada tingkat rendah dan $50 \%$ responden pada kelompok kontrol memiliki frekuensi halusinasi pada tingkat sedang. Hasil riset menunjukkan bahwa tindakan yang dilakukan dapat menurunkan kekambuhan halusinasi pada klien.

Angka kejadian di RSJ Prof Dr. Soerojo Magelang, selama bulan Januari-November 2015 dari 6 diagnosa besar yaitu gangguan persepsi sensori: halusinasi, resiko perilaku kekerasan, perilaku kekerasan isolasi social, defisit perawatan diri dan harga diri rendah, dari 8548 klien peringkat klien dengan diagnose gangguan persepsi sensori: halusinasi pada urutan ke 1 dengan rincian sebagai berikut: persepsi sensori: halusinasi 5389 jiwa (63\%), resiko perilaku kekerasan 1598 $(18,6 \%)$, perilaku kekerasan $3(0,03 \%)$, defisit perawatan diri 1109 jiwa $(12,9 \%)$, harga diri rendah 435 jiwa $(5,08 \%)$, dan sisanya isolasi social sebanyak 293 jiwa (3,42\%). Berdasarkan data tersebut bisa dilihat bahwa penderita ganggaun jiwa yang mendominasi adalah penderita dengan 
Murni Pratiwi, Heri Setiawan

Tindakan Menghardik Untuk Mengatasi Halusinasi Pendengaran Pada Klien Skizofrenia Di Rumah Sakit Jiwa

diagnosa keperawatan gangguan persepsi sensori: halusinasi (Adi, 2016). Di rumah sakit jiwa Indonesia, sekitar $70 \%$ halusinasi yang dialami oleh klien gangguan jiwa adalah halusinasi suara (Yosep, 2014). Halusinasi menjadi diagnosis terbesar yang dialami oleh para klien. Berdasarkan latar belakang tersebut penulis melakukan penelitian dengan judul "Tindakan Menghardik Untuk Mengatasi Halusinasi Pendengaran Pada Klien Skizofrenia Di Rumah Sakit Jiwa.

\section{METODE DAN BAHAN}

Dalam studi kasus ini teknik pengumpulan data yang dilakukan adalah sebagai berikut:

a. Wawancara

Penulis menggunakan teknik wawancara untuk mendapatkan data subjektif dan informasi tentang permasalahan yang dihadapi klien gangguan persepsi sensori: halusinasi pada skizofrenia serta perkembangan kondisi klien setelah dilakukan tindakan keperawatan menghardik halusinasi.

b. Observasi Langsung

Melakukan pengamatan langsung pada keadaan klinis klien dan mencatat hasil tindakan keperawatan menghardik halusinasi yang diberikan pada klien dengan skizofrenia di RSJ Prof. Dr. Soerojo Magelang

Teknik analisis yang digunakan penulis menggunakan metode deskriptif. Data yang diperoleh meliputi mendengar suara yang pada dasarnya tidak nyata, kurang konsentrasi dengan lingkungan sekitar, sulit berkomunikasi dengan orang lain, ekspresi muka tegang, pergerakan mata cepat, respon verbal yang lambat. Dari data yang diperoleh dapat disimpulkan rumusan masalahnya adalah gangguan persepsi sensori halusinasi.

Analisa data dari perumusan masalah gangguan persepsi sensori: halusinasi untuk mengatasi masalah tersebut penulis menggunakan tindakan menghardik halusinasi. Melatih klien dengan mengontrol halusinasi dengan cara mengendalikan halusinasi.

Instrumen alat ukur yang digunakan pada gangguan persepsi sensori: halusinasi adalah penulis itu sendiri, lembar atau format fokus pengkajian pada klien dengan gangguan persepsi sensori: halusinasi, lembar observasi penilaian (Damaiyanti, 2014).

\section{HASIL DAN PEMBAHASAN}

Penulis melakukan tindakan keperawatan pada klien gangguan persepsi sensori: halusinasi yaitu dengan tindakan keperawatan menghardik halusinasi untuk mengusir halusinasi. Untuk mengukur keberhasilan tindakan keperawatan menghardik halusinasi penulis menggunakan lembar observasi sebelum dan sesudah dilakukan tindakan keperawatan menghardik halusinasi.

Berdasarkan hasil studi kasus pada klien Skizofrenia dengan gangguan persepsi sensori: halusinasi dari pengkajian dan observasi penulis mendapatkan kesenjangan saat melakukan pengkajian dan melakukan tindakan. temuan batasan karakteristik pada Sdr. Sa, dan Sdr. So yang mendukung pada masalah gangguan persepsi sensori: halusinasi yaitu klien mendengar suara-suara yang pada dasarnya tidak nyata, kontak mata yang mudah beralih, sulit konsentrasi, respon verbal yang lambat, ekspresi wajah tegang, sulit berkomunikasi dengan orang lain menurut (Prabowo, 2014).

Berdasarkan pengkajian, teori dan kasus pada Sdr. S dan Sdr. S ditemukan adanya kesesuaian antara teori dengan tanda dan gejala yang muncul pada Sdr. Sa dan Sdr. So, jadi diagnosa yang di tentukan oleh penulis sudah sesuai dengan teori yang ada (Dermawan, 2015). Data yang diperoleh menunjukkan penyebab dari klien Skizofrenia mengalami halusinasi adalah pengaruh dari faktor predisposisi 
yaitu faktor studi neurotransmiter dan faktor genetik, karena klien belum bisa melakukan menghardik halusinasi secara benar sehingga klien masih sering mengalami halusinasi yang mengganggu klien. Oleh karena itu klien dengan gangguan persepsi sensori: halusinasi perlu mendapatkan perawatan halusinasi sehingga dapat mengontrol halusinasi jika datang menyerang.

Prinsip pelaksanaan dalam mengatasi masalah gangguan persepsi sensori: halusinasi adalah salah satunya dengan melakukan menghardik halusinasi. Menghardik halusinasi adalah upaya mengendalikan diri terhadap halusinasi dengan cara menolak halusinasi yang muncul (Dalami, 2010). Menghardik halusinasi bertujuan untuk mengusir halusinasi yang dialami klien.

Menurut hasil riset Karina (2013) saat melakukan terapi menghardik responden menjadi lebih fokus dan berkonsentrasi pada halusinasinya. Sehingga memungkinkan beberapa zat kimia di otak seperti dopamine neurotransmitter tidak berlebihan. Klien dilatih untuk mengatakan tidak terhadap halusinasi yang muncul atau tidak memperdulikan halusinasinya. Jika bisa dilakukan dengan baik dan benar, maka klien akan mampu mengendalikan diri dan tidak mengikuti halusinasi yang muncul. Teknik untuk menghardik halusinasi itu sendiri adalah fokus pandangan lurus ke depan kemudian konsentrasi, memilih kata yang akan digunakan untuk menghardik, perawat mendemonstrasikan kemudian klien diberi kesempatan mendemonstrasi kembali. Kata yang sudah dipilih diucapkan dengan sungguh-sungguh dapat dilakukan dalam hati atau diucapkan langsung. Setelah latihan menghardik penulis memberikan reinforcement pada klien.

Hasil perbedaan dari tindakan yang dilakukan sebelum dan sesudah dilakukan tindakan menghardik halusinasi, penulisan ini terbukti ada perbedaan. Hasil pengkajian yang diperoleh dari Sdr. Sa dihari pertama yaitu tanda dan gejala yang muncul yaitu tidak dapat membedakan keadaan yang nyata atau tidak, kurang konsentrasi dengan lingkungan sekitar, sulit berkomunikasi dengan orang lain, ekspresi muka tegang, pergerakan mata cepat dan respon verbal yang lambat. Pada kedua klien terdapat kesenjangan perbedaan tipe skizofrenia, pada Sdr. Sa dengan diagnosa medis skizofrenia tipe tak terinci.

Menurut Hawari (2012) skizofrenia tipe tak terinci gejalanya memenuhi kriteria, namun tidak memenuhi kriteria tipe paranoid, hebefrenik, atau katatonik. Tipe ini ditandai dengan gejala skizofrenia campuran (tipe lain) disertai afek datar atau afek yang tidak sesuai secara nyata, inkoherensi, asosiasi longgar dan disorganisasi perilaku yang ekstrem. Sdr. Sa saat berinteraksi dengan penulis selama empat hari terkadang kata yang diucapkan oleh klien tidak berhubungan antara satu sama lain, dimana membuat penulis berkali-kali mengulang kata yang telah diucapkan.

Sedangkan pada Sdr. So saat dilakukan pengkajian pada hari pertama diperoleh tanda gejala yang muncul yaitu tidak dapat membedakan keadaan yang nyata atau tidak, kurang konsentrasi dengan lingkungan sekitar, sulit berkomunikasi dengan orang lain, ekspresi muka tegang, pergerakan mata cepat, respon verbal yang lambat dan takut. Diagnosa medis pada Sdr. So merupakan skizofrenia tipe paranoid.

Menurut Prabowo (2014) gejala yang muncul pada tipe paranoid adalah waham kejar atau waham kebesaran, halusinasi yang mengandung isi kejaran atau kebesaran, gangguan alam perasaan dan perilaku, misalnya kecemasan yang tidak menentu, kemarahan, suka bertengkar, dan seringkali ditemukan kebingungan. 
Disini ketika penulis berinteraksi dengan klien, klien mengatakan merasa pusing karena sendirian dan takut. Menurut pengamatan penulis Sdr. So jarang berinteraksi dengan klien lain di bangsal Gatot Kaca, klien lebih sering di tempat tidurnya dan menyendiri. Gejala yang timbul dibuktikan dengan kekambuhan klien pada hari ketiga dimana halusinasi klien menjadi sangat kuat, klien tampak ketakutan, dan mengikuti isi halusinasinya.

Hari kedua klien Sdr. Sa terlihat masih bersikap menutup diri berbicara seperlunya saja dalam berkomunikasi perlu beberapa kali sentuhan untuk membantu klien fokus terhadap lawan bicara. Disini klien sudah mampu melakukan latihan menghardik secara mandiri. Setelah selesai latihan menghardik klien mengatakan merasa lebih tenang, klien bersedia melakukan latihan menghardik ketika halusinasi datang dan tanda gejala yang muncul pada klien masih sama seperti pada hari pertama. Pada Sdr. So respon klien ketika berkomunikasi dengan penulis bersikap menutup diri berbicara hanya seperlunya, kontak mata yang mudah beralih dan perlu beberapa kali sentuhan atau pertanyaan ulang saat berkomunikasi dengan klien. Sdr. So pada hari kedua mampu melakukan latihan menghardik secara mandiri. Setelah latihan menghardik klien mengatakan pikiran lebih "padang". Tanda gejala yang muncul pada hari kedua masih sama seperti pada hari pertama.

Kemudian pada hari ketiga Sdr. Sa tampak tenang kembali bersedia berinteraksi dengan penulis. Klien dapat melakukan latihan menghardik secara mandiri dan klien mengatakan melakukan latihan menghardik setiap halusinasinya datang walau tanpa pengawasan dari penulis. Tanda gejala yang masih muncul pada klien yaitu kurang konsentrasi terhadap lingkungan sekitar, sulit berkomunikasi dengan orang lain, ekspresi muka tegang, pergerakan mata cepat, dan respon verbal yang lambat. Pada Sdr. So dihari ketiga mengalami kekambuhan, klien di restrain oleh perawat bangsal Gatot kaca. Klien tampak bingung, takut, dan gelisah. Penulis tetap berusaha untuk berkomunikasi dengan klien dan melakukan latihan menghardik, klien saat latihan menghardik perlu bimbingan dari penulis dan ketika berkomunikasi klien hanya mengangguk dan menggelengkan kepala saja. Klien mengatakan mengikuti isi dari halusinasinya. Respon setelah latihan menghardik mengatakan tenang dan halusinasinya hilang ketika klien berkomunikasi dengan penulis.

Studi kasus yang telah dilakukan diperkuat dan dibuktikan dengan teori menurut Dermawan (2013), gejala yang timbul pada skizofrenia salah satunya halusinasi. Tindakan yang dilakukan untuk mengatasi halusinasi salah satunya adalah menghardik halusinasi, dengan latihan menghardik halusinasi klien akan mampu mengendalikan diri dan tidak mengikuti halusinasi yang muncul. Serta membantu memutus isi dari halusinasi.

Pada masalah ini sangat perlu adanya peningkatan tindakan latihan menghardik halusinasi, dan dilanjutkan peningkatan tindakan berlanjut seperti latihan bercakap-cakap dengan orang lain, melakukan kegiatan secara terjadwal dan rutin mengkonsumsi obat. Banyak faktor yang mempengaruhi klien untuk mendorong klien agar lebih semangat dalam mencapai kesembuhannya salah satunya adalah dari diri sendiri. Kemudian dorongan dari keluarga atau orang-orang terdekat dalam peningkatan mutu kualitas hidupnya seperti sering menjenguk pasien atau dapat mendampingi klien ketika melakukan kegiatan.

\section{KESIMPULAN}

Hasil pengkajian klien skizofrenia dengan gangguan persepsi sensori: 
halusinasi pada Sdr. Sa dan Sdr. So menunjukkan batasan karakteristik yang muncul adalah sebagai berikut tidakl dapat membedakan keadaan yang nyata atau tidak, kurang konsentrasi dengan lingkungan sekitar, sulit berkomunikasi dengan orang lain, ekspresi muka tegang, pergerakan mata cepat, respon verbal lambat, dan takut.

Batasan karakteristik yang di dapatkan melalui pengkajian tersebut masalah keperawatan yang muncul pada Sdr. Sa dan Sdr. So adalah gangguan persepsi sensori: halusinasi. Rencana tindakan atau intervensi utama pada Sdr. Sa dan Sdr. So adalah tindakan menghardik halusinasi dengan mengidentifikasi jenis halusinasi, isi halusinasi, waktu terjadinya halusinasi, situasi halusinasi dan respon klien terhadap halusinasi.

Hasil evalaluasi terhadap masalah klien skizofrenia dengan gangguan persepsi sensori: halusinasi pada Sdr. $\mathrm{Sa}$ dan Sdr. So didapatkan bahwa efektifitas setelah dilakukan latihan menghardik halusinasi terhadap kedua klien ditunjukan dengan adanya penurunan tanda gejala yang terdapat pada klien Sdr. Sa yaitu $87 \%$ sedangkan pada Sdr. So yaitu $67 \%$.

\section{DAFTAR PUSTAKA}

Adi, Seno P. (2016). Asuhan Keperawatan Jiwa Gangguan Persepsi Sensori: Halusinasi Pendengaran Pada Tn. S di Wisma Antareja RSJ Prof. Dr. Soerojo Magelang. Stikes Muhammadiyah Pekajangan Pekalongan.

Ambarwati, Wahyu N. (2010). Kefektifan Cognitive Behaviour Therapi (CBT)Sebagai Terapi Tambahan Pasien Skizofrenia Kronis Di Panti Rehabilitasi Budi Makarti Boyolali. Fakultas Kedokteran Universitaas Sebelas Maret Surakarta.
Anggraini, Karina. (2013). Pengaruh Menghardik Terhadap Penurunan Tingkat Halusinasi Dengar Pada Pasien Skizofrenia Di RSJ Dr. Aminogondohutomo Semarang. STIKES Telogorejo Semarang.

Dalami, E.Susilawati, Rochimah, Ketut, RS, \&Widji, L. (2010). Konsep Dasar Keperawatan Kesehatan Jiwa. Jakarta: Cv. Trans Info Media.

Dermawan, Deden. (2013). Keperawatan Jiwa: Konsep dan Kerangka Kerjal Asuhan Keperawatan Jiwa. Yogyakarta: Goysen Publishing.

Direja, A.H.S. (2011). Buku Ajar Asuhan Keperawatan Jiwa. Yogyakarta: Nuha Medika.

Fitria, N. (2009). Prinsip Dasar dan Aplikasi Penulisan Laporan Pendahuluan Dan Strategi Pelaksanaan Tindakan Keperawatan (LP dan SP). Jakarta:Salemba Medika.

Hawari, D. (2012). Skizofrenia Pendekatan Holisik (BPSS) Bio-Psiko-Sosio Spiritual. Jakarta: Balai Penerbit FKUI.

Katona, Cornelius. (2012). At a Glance PSIKIATRI. Edisi ke 4. Alih bahasa: Dr. Cut Noviyanti, Dr. Vidya Hartiyansyah. Jakarta: Erlangga.

Keliat, Budi Anna. (2011). Manajemen Kasus Gangguan Jiwa: CMHN (INTERMEDIATE COURSE). Jakarta: EGC.

Muhith, Abdul. (2015). Pendidikan Keperawatan Jiwa Teori \& Aplikasi. Edisi I. Yogyakarta: CV Andi Offset.

Mukhripah, Damaiyanti. (2014). Asuhan Keperawatan Jiwa. Cetakan Kedua. Bandung: PT Refika Aditama.

Prabowo, Eko. (2014). Buku Ajar Keperawatan Jiwa. Cetakan 
Pertama. Yogyakarta: Nuha Medika.

Pravitasari, Galuh Ayu. (2015). Gambaran Manajemen Gejala Halusinasi Pada Orang Dengan Skizofrenia (ODS) Di Ruang Rawat Inap RSJD Dr.Aminogondohutomo

Semarang.

Fakultas

Kedokteran Universitas Diponegoro Semarang.

Retno, Ninik Widuri. (2016). Upaya Penurunan Intensitas Halusinasi dengan Cara Mengontrol Halusinasi di RSJD Dr. Arif Zaenudin Surakarta. Fakultas Ilmu Kesehatan Universitas Muhammadiyah Surakarta.

Stuart, Gail W. (2013). Buku saku Keperawatan Jiwa/alih Bahasa: Ramona P. Kapoh, Egi Kornara. Edisi 5. Jakarta: EGC.

Suheri. (2014). Pengaruh Tindakan Generalis Halusinasi Terhadap Frekuensi Halusinasi Pada Pasien Skizofrenia Di RS Jiwa Grhsia PEMDA DIY. Program Studi Ilmu Keperawatan Sekolah Tinggi Ilmu Kesehatan 'Aisyiyah Yogyakarta.

Videbeck, Sheila I. (2008). Buku Ajar KeperawatanJiwa, alih bahasa: Renata Komalasari. AlfrinaHany. Jakarta: EGC.

Yosep, I \& Titin, S. (2014). Buku Ajar Keperawatan Jiwa. Bandung: Refika Aditama. 